\title{
THE PACIFIC WALRUS
}

\section{By Karl W. Kenyon}

During recent years there have been repeated reports of extravagant exploitation of the walrus by Eskimos and these have been strengthened by aerial observation of many headless carcasses on beaches of the Bering Sea. So in 1958 the United States Fish and Wildlife Service decided upon an inquiry into the Pacific Walrus, and its hunting and utilization by Eskimo in the Bering Sea region.

Biologists from the Department of Health, Education and Welfare, and the Alaska Department of Fish and Game cooperated in the work. Studies were conducted on St. Lawrence Island by Dr. Francis H. Fay and Mr. Averill Thayer, on Little Diomede Island by the late Mr. Stanley S. Fredericksen and the author, and on Round Island of the Walrus Islands in Bristol Bay, by Dr. Fay, Mr. James W. Brooks and the author. Dr. John L. Buckley of the Fish and Wildlife Service counted walruses on the ice of the northern Bering Sea from the air. The Eskimo hunters freely gave us their co-operation and good will, and this alone made the study possible.

The economic incentive to exploit pinnipeds for oil and hides decreased after the chaotic slaughter of the eighteenth and nineteenth centuries when many species were seriously depleted. During the present century those which have continued to yield valuable products, such as elephant seals (Mirounga) and fur seals (Callorhinus and Arctocephalus), have been conserved. The Pacific walrus occupies a unique position in that the demand for its ivory, both carved and unworked, or raw, has increased in recent years, whereas measures introduced for conservation of the walrus have not yet been effective.

Our study of the Walrus-Eskimo problem indicates danger to the continued existence of this useful creature. The philosophy of the Eskimo from ancient times has been to take all available animals when hunting was good and unfortunately his attitude has not changed with the advent of modern equipmentbinoculars, rifles, outboard motors. One Eskimo said to me " the ivory is the Eskimo's white gold, and the more he can acquire the better". He wanted to use a "walkie-talkie", so that a hunter stationed high on the island might direct boats below to walruses hidden by ice floes.

\section{Economics}

Certain natives kill many more walruses than they need for ivory carving, food and boat coverings. In some areas they 
slaughter as many walruses as is physically possible. Sometimes tusks only are taken and the remainder of the carcasses wasted, a practice called "head hunting". The tusks which are of high value but of little bulk compared with the rest of the carcass, are often sold in a raw state, even though many Eskimo who thus dispose of them are excellent carvers. Carved ivory may be worth roughly $\$ 25$ to $\$ 100$ per pound, while raw ivory sells for $\$ 1$ to $\$ 2$. Ivory carvings are in great demand. Their annual retail value has been estimated at more than $\$ 150,000$. Non-natives who practise the art of carving, as well as souvenir collectors, both of whom buy raw ivory, furnish the economic incentive which has resulted in excessive exploitation of the walrus.

Four American Eskimo villages on islands in the Bering Sea depend primarily on the walrus-Ignalook (Little Diomede), Ukivok (King Island), Gambell and Savoonga (St. Lawrence Island). Eskimo of several other coastal villages depend on the walrus to a lesser extent. The estimated annual take by all villages on the American side of the Bering Strait is 1,100 walruses. On the Soviet side intensive walrus hunting is apparently carried on with an estimated annual take of 5,000. The natives of Big Diomede Island have now been moved to East Cape, Siberia. One of these who returned to Big Diomede in the winter of 1958 to hunt, and visited Little Diomede, said that in 1957 East Cape hunters took about 900 walruses of both sexes and all ages.

The number of beaches where adult male walruses haul out in the summer has been greatly reduced since the early years of the present century. In 1786, when the Pribilof Islands were discovered, a considerable number resorted to Walrus Island of this group. They were unremittingly slaughtered for their ivory until 1891 when the last was killed. Kleynenberg reports that of 33 coastal walrus hauling grounds on the Chukotsk Peninsula of the Soviet Union only three remained by 1954 . This reduction of hauling grounds is undoubtedly an indication of the decrease in the total Bering Sea walrus population. Fay estimated that the total population of the Pacific walrus has dropped from over 200,000 between 1650 and 1790 to 45,000 in the 1950-1956 period. Some biologists believe, however, that the latter estimate is too low.

\section{Natural History}

Among seal-like marine mammals (Pinnipedia) the walrus (family Odobenidae) is ranked between eared seals (Otariidae) 
and earless seals (Phocidae). It shares certain characteristics of each. Superficially it is like the phocids in that it lacks an external ear, but it shares basic structural characters with otarids, such as the ability to rotate the hind flipper forward and so walk on a solid surface. In size, the walrus is second to the elephant seal. A large male weighed 3,432 pounds and a female 1,500 pounds. Newly born calves may weigh up to 150 pounds.

The hairy coat is short and light rusty brown in colour. While moulting the "warty" skin of the male becomes hairless. It is whitish in cold water but becomes quite pink when the animal rests in warm sunlight. Examination of dentine layers on teeth has shown that expectancy of life is from 20 to 30 years.

Paired air sacs in the neck of the walrus may be inflated, holding the head of the sleeping animal above the surface of the sea. They may have other unknown functions. Apparently this structure is possessed by no other pinniped.

The walrus is also set apart from other marine mammals by its heavy canine teeth or tusks, which in the male may reach a length of 39.5 inches and a weight of 12 pounds. Those of the female are slimmer and lighter. Characteristically the walrus is associated with ice packs where it hauls out, aided by its tusks, to sleep and bear young. Large groups of males also gather in late spring and summer on terrestrial hauling-out grounds, where they moult.

The walrus is a bottom feeder. The stomach contents consist predominantly of clam meat, without shells. The structure of the mouth and tongue can produce suction, like that in a vacuum cleaner. Apparently meat and shells are thus separated and the shells discarded. Chewing is improbable. The undamaged clam meat from a slaughtered walrus is often eaten (after rinsing in sea water) by Eskimo hunters.

Male walruses may reach sexual maturity at the age of about six years, females at five to seven years. The mother walrus cares for her calf for an unusually long period, among pinnipeds. The calf nurses for nearly two years and often rides on its mother's back as she travels north in the spring. Usually only one calf is produced, though several twin foetuses are recorded. The mother may become pregnant again when her calf is one or two years old. Most young are born in April and May after a gestation period of about one year. Eskimo legend has it that adoption of orphan calves by foster mothers takes place, but to the writer it seems improbable that a female would nurse a 
calf other than her own. Other pinnipeds are known not to tolerate orphans. Much is still to be learned about social behaviour, such as harem formation and territoriality.

\section{Walrus Hunting}

\section{Little Diomede}

On 11th May, 1958, when Fredericksen and I arrived at Ignalook Village, Little Diomede, the island was icebound. Hunting began on 16th May and was practically finished by the time I departed on 14th June, when virtually all ice had passed northward into the Chukchi Sea.

Until 4th June the ice shelf between the Little and Big Diomede remained intact and hunting was conducted from the south tip of the island. To reach this the hunters, assisted by dog teams, hauled their boats a mile over the ice. When the possibility of open water existed the hunters often slept on shelves of the granite cliffs, or in the boats hauled up on shore ice. A lookout with binoculars kept a constant watch for open leads and for walruses.

The number of walruses passing Little Diomede through the eastern Bering Strait during the study period could be estimated roughly at between five and ten thousand. Between 1,900 and 2,100 were actually seen. Fog often reduced visibility but walruses could still be heard bawling.

While the ice was breaking up and passing through Bering Strait, the Eskimo were often at sea hunting from their umiaks throughout the 24 daylight hours. From the hundred Eskimo at Ignalook there were enough hunters to man four boats. These were wooden framed, from 20 to 30 feet long, covered with walrus skins and powered by 15, 20 and 30 horsepower outboard engines. Each carried 6 to 13 hunters (usually 6 to 8 ) and often went 4 to 10 miles out to sea-sometimes 30 miles. While Fredericksen and I were there the Eskimo made 57 hunting trips, representing $\mathbf{5 8 0}$ hunting hours.

The boat owner is nominally in charge of the boat, usually handles the motor and determines the areas to be hunted, otherwise the hunters appear quite unorganized. Shooting may begin beyond effective range and a poor marksman may start it. Nobody minds about bad or hasty shooting, or tries to correct poor technique such as failure to harpoon a floating walrus before it sinks. There is a traditional fatalistic attitude toward losses. During eight hunting trips when over 360 shots were fired at more than 70 walruses, only 23 animals were taken, 
but at least 37 were either mortally wounded or killed outright and sank.

When walruses are encountered singly or in small groups, a conscientious attempt is made to save all their meat and skins. When large groups are encountered, wholesale killing takes place. In 1946 Albert Heinrich, a school teacher on Little Diomede, described hunting practices there in a letter: "When a boat spots a group of walruses in the ice, the procedure is simply to go over to the ice pan and when you get to almost point-blank range, everybody empties his rifle and the boat is pulled up on the ice. Sporadic shooting usually goes on at this stage, but there is more or less of a lull, giving the men time to reload for the returning walrus. The surviving individuals invariably return to make an attack. Their efforts, naturally, are rewarded by a counter attack of bullets. After one, two or three sessions of this, comparative quiet reigns, though an occasional walrus, often a wounded one coming up for air, will be seen and fired upon-the resultant gore is indescribable." This account is adequate to illustrate what we saw in 1958 .

Two large kills which resulted primarily in head hunting took place during our study. On 24th May 30 adult females, each accompanied by a calf, were known to be killed. Fourteen animals sank immediately. From the remaining 16 adults, the tusks and a total of about 200 pounds of meat were taken, as were two of the 30 or so calves. The remaining meat, skins and calves were abandoned. Nearby on the ice were 18 headless adult female carcasses, previously killed by Eskimo of another village. Neither of us observed the second big kill on 4th June but when the boat reached the village it contained the tusks from 20 adult females and one male. Six whole calves, about 250 pounds of additional meat and the skin of one adult female were also saved.

If walruses are scarce an attempt is made to kill every individual. If abundant, females (especially those with calves) are chosen because their ivory is better for carving, their meat is easier to butcher and more tender, and their skins are of more value for boat coverings. For example - on the morning of 6th June we sighted a lone bull and gave chase. After several volleys had been fired, probably wounding this animal, a female and calf were sighted. Immediately the bull was abandoned. $E n$ route to the female another bull was sighted and fired upon, but without altering course. The female was killed but when a timid hunter failed to throw his harpoon, the calf climbed on to her carcass, sinking it. 


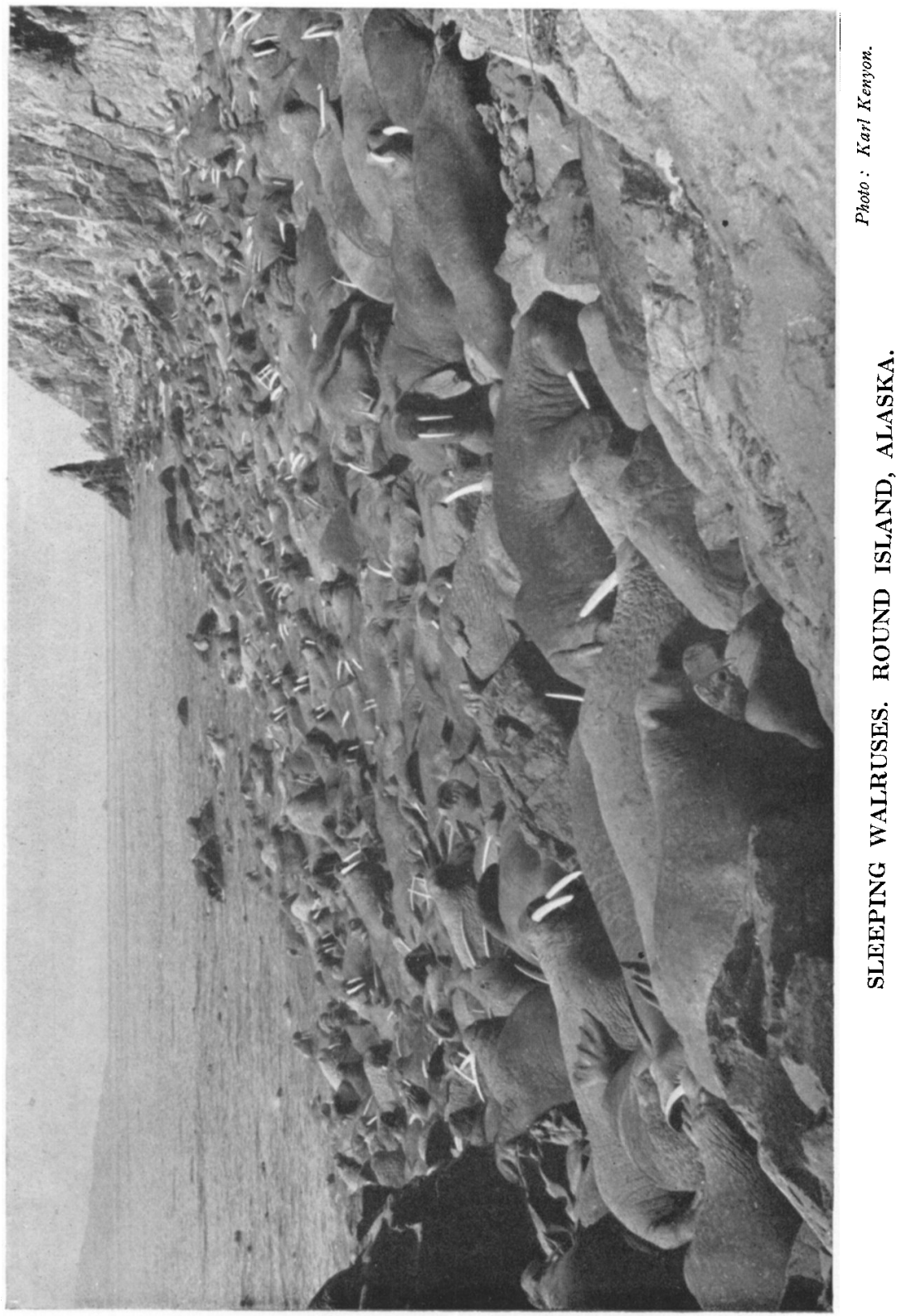




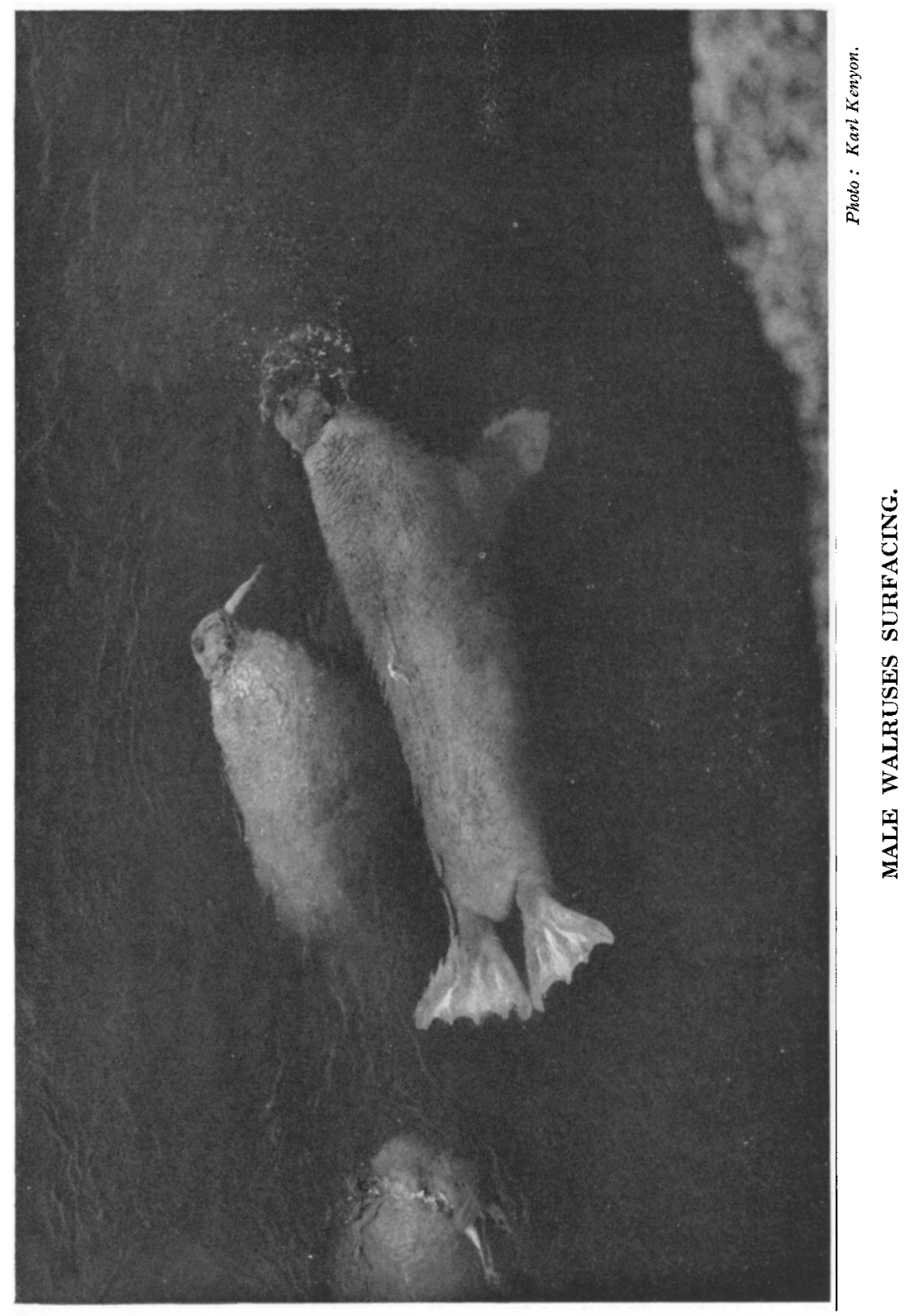




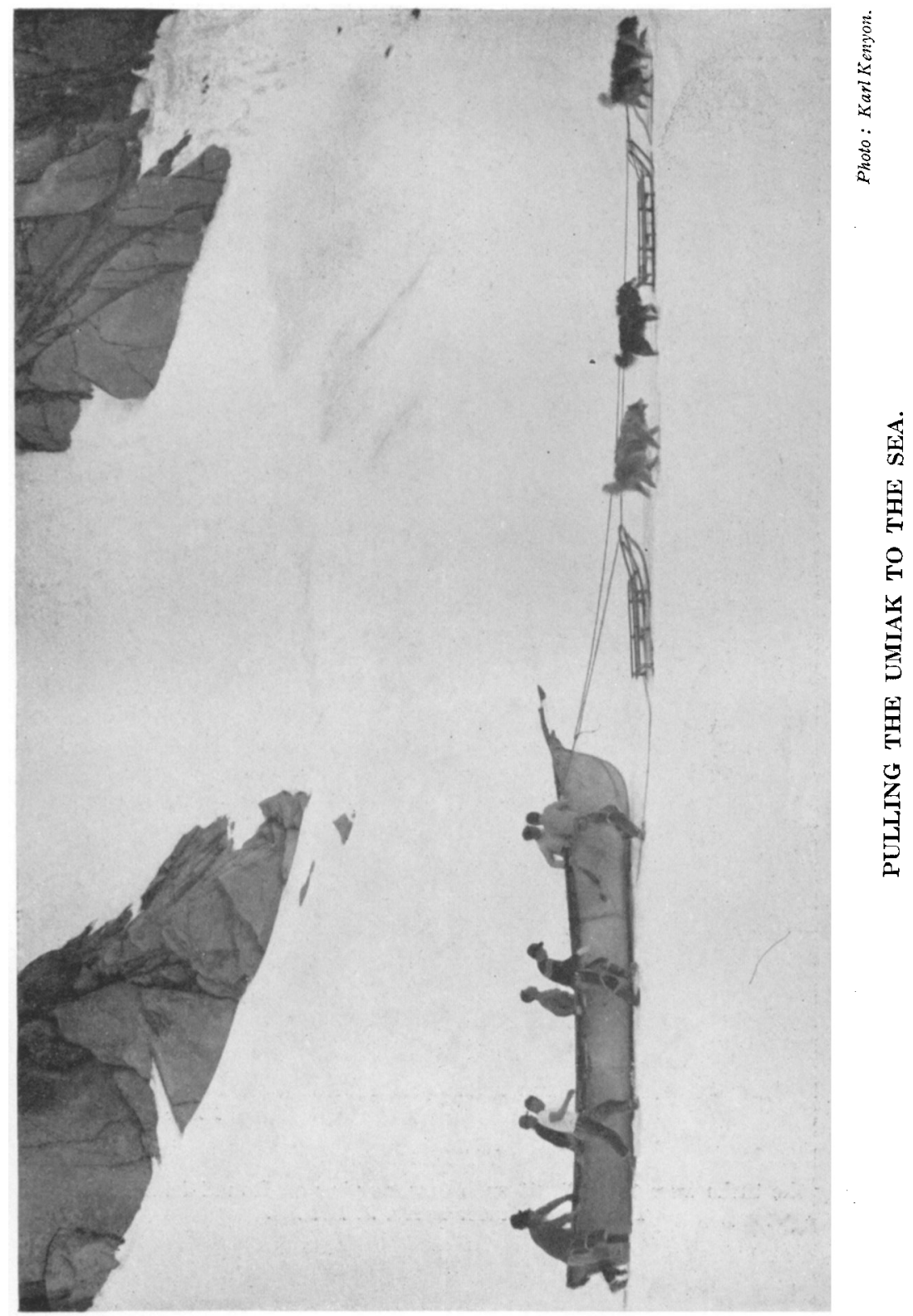




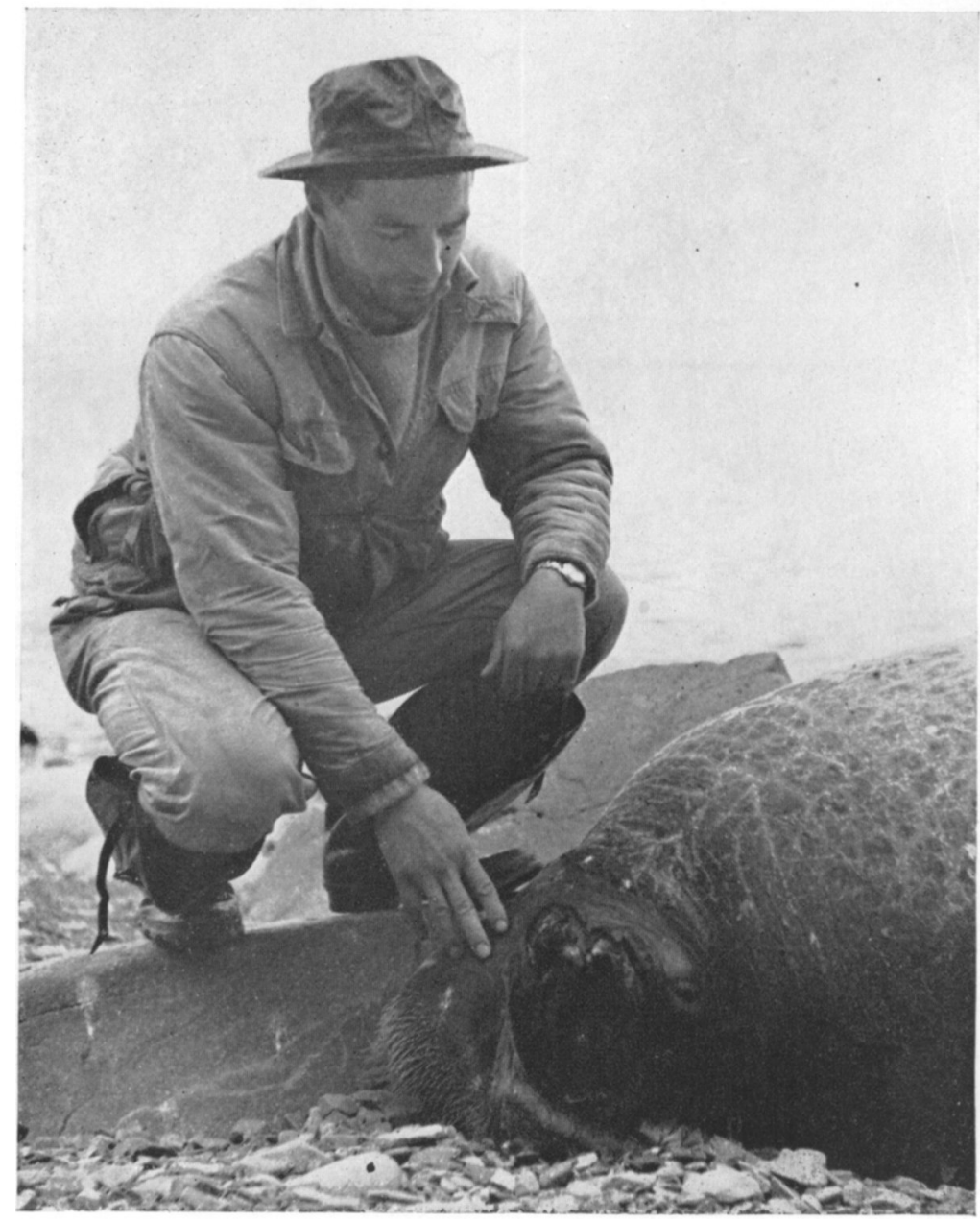

Photo: Karl Kenyon.

WASTE

"Only the tusks were taken." 39 such carcasses lay on Round Island beach. The demonstrator is Mr. J. Brooks. 
At Little Diomede walruses are shot with guns of the following calibres, in order of popularity: 30-30, 25-35, 30-06, 0.308, 0.222 and 22 Hornet. Some of these calibres possess insufficient penetrating power, resulting in the escape of mortally wounded animals. During spring, the important hunting season, the animals are shot from boats; in winter a small number are taken from the ice by hunters on foot.

The following is a summary of our records :Adult Walruses

(a) On ten hunting trips when records were kept by non-native observers :-

$\begin{array}{cccl}\text { Adult walruses killed } & \cdot & 55 \\ , " & \text { taken } & \text {. } & \mathbf{2 6}(47 \text { per cent) } \\ ", \quad \text { lost } & \text {. } & 29(53, ", ")\end{array}$

(b) Including trips when records were necessarily taken from hunters' reports :Adult walruses killed . 141

" , taken : 85 (60 per cent)

All walruses (including calves)

$\begin{array}{rlll}\text { Walruses killed } & \cdot & . & 245 \\ , \quad \text { taken } & \cdot & . & 117(48 \text { per cent) } \\ , \quad \text { lost } & . & . & 128(52,, \quad,)\end{array}$

The figures for walruses lost are minimal in all cases, for some fatally wounded animals escape undetected. The year 1958 was considered a poor one by the Eskimo of Little Diomede. They sometimes take more than $\mathbf{5 0 0}$ walruses in a season.

It must be remembered that the wasteful hunting practices at Little Diomede are not those of all Alaska Eskimo. At the St. Lawrence Island villages, F. H. Fay, during six seasons of study, found that head hunting was not practised. The localities where walrus hunting has been notably wasteful are Little Diomede, King Island and the Walrus Islands. But field data gathered by several observers in different areas confirms that of all walruses killed about half are lost.

\section{Trophy Hunting}

Trophy hunting for walrus was first authorized on 10th May, 1957. From then until the end of 1959 , sixteen licences had been sold and at least six walruses taken. It is an expensive and rigorous pursuit which is never likely to be followed on a large scale.

After spending nearly a week with a trophy hunter, I am convinced that such hunting helps to conserve the walrus, because male walruses only may be killed and the Eskimo accompanying the hunter is hindered or prevented from killing 
the females or females with young which he would otherwise have chosen. Wages paid by the trophy hunter might eventually tend to divert the incentive from wasteful killing.

\section{The Walrus Islands}

The only regular summer hauling grounds for walrus still in existence on United States territory are at the Walrus Islands in north-east Bristol Bay, Alaska. After a preliminary aerial survey, Brooks, Fay and I camped from 23rd to 28th June on a narrow beach of precipitous Round Island, the only one of this group of seven islands on which we found walruses. Here there were 1,500 to 2,000 males, both adult and immature. Most of them were hauled up on narrow cobble beaches skirting the base of sheer granite cliff more than 100 feet high. We also found carcasses of 39 animals. The tusks had been taken from all but three of them, but less than 100 pounds of the 117,000 pounds of available meat, hide and bone had been removed. A native of Togiak Village nearby told us that these animals had been killed by the local hunters several weeks before.

Most of the walruses we saw were moulting. Many were completely hairless. They were not easily alarmed when approached quietly upwind and we were able to place metal tags on the flippers of 12 resting individuals.

As a result of our survey we came to the conclusion that the Walrus Islands in Bristol Bay should be set aside as a walrus refuge and our opinion was strengthened when Virgil Crosby, the local Fish and Wildlife Service Agent, obtained the conviction of some Togiak villagers whom he caught in the act of wastefully slaughtering walruses at the Round Island hauling ground. Subsequently-from 4th June, 1960-the Alaska Government designated these islands the "Walrus Islands State Game Sanctuary" but already the natives of Togiak Village have petitioned for special hunting privileges there.

\section{Legal Considerations}

No international agreement exists to protect the Pacific walrus and it is taken on the high seas by nationals of the U.S.A. and the U.S.S.R. A bill (H.R. 8164) for the protection of marine mammals on the high seas, designed to give the Secretary of the Interior broad powers to conserve the walrus, polar bear and sea otter, was introduced in the House of Representatives on 9th July, 1959. Such a law would permit the control of American nationals on the high seas but an international agreement would still be needed. 
Within territorial waters of the United States, Public Law 219, H.R. 1606, approved on 18th August, 1941, and amended in 1956, gave the walrus some protection within territorial waters of the United States, but was found impossible to enforce in practice. Harsh weather and adverse ice conditions have afforded the walrus its only real protection.

Our study took place while Alaska was still a Territory of the United States and the walrus was a Federal responsibility. On 1st January, 1960, the State of Alaska assumed responsibility for walrus management, and new regulations permit residents of Alaska, after purchasing a hunting licence, to take an unlimited number of bull walruses and seven female or immature walruses of either sex. Non-resident hunters are limited to one bull walrus, under special permit. There is no closed season except in one area of northern Bristol Bay. To some biologists the new regulations appear to allow extravagant exploitation but in view of certain restrictions on possession, sale, use and transport of walrus products, judgment on their final effect must be reserved. If the new laws are effectively enforced, the take of walruses may possibly be kept within safe limits.

\section{Conclusions}

The Pacific walrus is not in immediate danger of extermination, but there is evidence that its population is steadily declining. It may reach a dangerous point in a few years, unless effective conservation legislation is enacted, both State and international. Modern equipment, the economic incentive to take ivory, the Eskimo tradition of hunting to the limit, all have worked together to perpetuate a critical situation. The existing walrus population is probably sufficient to fulfil the needs of both Eskimo and trophy hunter, if regulations can be enforced and conservative exploitation practised.

Conservation education among the Eskimo people is required. The number of walruses necessary to satisfy the needs of each village should be ascertained and the taking of walruses limited to that number. Wasteful practices, economical and biological, should be replaced by the complete use of each animal taken, and by reasonable restrictions on the killing of female walruses. Trophy hunting can act as a favourable conservation factor. Above all we believe that the economic incentive to kill walruses for their ivory only must be eliminated.

The new regulations of the State of Alaska may accomplish their purpose if strict enforcement is possible, although some 
biologists believe that the number of walruses which may lawfully be taken is unrealistically high. The Alaska Department of Fish and Game is undertaking further population surveys and other biological studies.

\section{REFERENCES}

Brooks, J. W., 1954. A contribution to the life history and ecology of the Pacific walrus. Alaska Coop. Wildl. Res. Unit [College, Alaska] Spec. Rept., 1, $9+103$ pp.

Buckley, J. L., 1958. The Pacific walrus. U.S. Dept. Interior, Fish and Wildlife Service, Spec. Sci. Rept. Wildl., 41, 29 pp.

Dunbar, M. J., 1956. The status of the Atlantic walrus, Odobenus rosmarus (L.), in Canada. Proc. and papers 5th Tech. Meet. of International Union for the Protection of Nature, pp. 59-61.

FAY, F. H., 1957. History and present status of the Pacific walrus population. Trans. 22nd N. Amer. Wildl. Conf., 431-445. 1958. Pacific walrus investigations on St. Lawrence Island, Alaska. Alaska Coop. Wildl. Res. Unit [College, Alaska], 54 pp.

Kleynenberg, S. Ye., 1957. On preserving the walrus. Priroda (7), pp. 101-103.

Nikulin, P. G., 1954. On twinning of Chukotsk walrus. Bull. Pacific Sci. Inst Fish. Oceanog., Vladivostok, 39, 353.

Preble, E. A., and W. L. McAtee, 1923. Birds and mammals of the Pribilof Islands, Alaska. North Amer. Fauna No. 46, p. 106. 